\title{
EU Relations with the BRICS: Strategic Partnership or Structural Disjunction?'
}

\author{
M.R. Freire
}

Maria Raquel Freire - PhD, Associate Professor, Jean Monnet Chair, Department of International Relations, Faculty of Economics of the University of Coimbra; Av. Dias da Silva 165, 3004-512 Coimbra, Portugal; E-mail: rfreire@fe.uc.pt

\begin{abstract}
The international system is characterized by increasingly interdependent and asymmetrical relations between the constellations of actors that compose it. While the state remains a central reference in international relations, multilevel and multidimensional relationships make the system very complex. The state, international organizations, non-state actors, club diplomacy and groups of states (e.g., the Group of 20 [G20] and the BRICS grouping of Brazil, Russia, India, China and South Africa) all contribute to this complexity and make the global governance system increasingly multifaceted. In this context, this article examines the relationship between the European Union and the BRICS - two very different actors, pursuing formal and informal integration processes, respectively - and assesses the possibilities and limits of cooperation. This article seeks to understand whether the EU-BRICS relationship reflects a strategic partnership or a structural disjuncture. It starts by discussing multilateralism as a cooperation-oriented but sometimes interest-driven tool in a diverse and multilevel governance system. It then analyses EU - BRICS relations, identifying the main drivers and highlighting how the complex context both facilitates and hinders the constitution of this relationship. The article concludes that the EU - BRICS relationship is informed by asymmetries and ambivalence that reflect their different sizes, capacities and approaches. Moreover, although there is a shared understanding that cooperation might be beneficial, contradictory rules and perspectives on the international order mean this potentially positive relationship is nevertheless embedded in fundamental structural constraints.
\end{abstract}

Key words: European Union; BRICS; global governance; multilateralism; norms

For citation: Freire M.R. (2017) EU Relations with the BRICS: Strategic Partnership or Structural Disjunction? International Organisations Research Journal, vol. 12, no 2, pp. 182-200 (in Russian and English). DOI: 10.17323/1996-7845-2017-03-182

${ }^{1}$ The editorial board received the article in November 2017.

The author acknowledges funding for research from the Marie Skłodowska-Curie Innovative Training Networks (ITN-ETN) of the European Union's Horizon 2020 research and innovation programme, under grant agreement "CASPIAN - Around the Caspian: A Doctoral Training for Future Experts in Development and Cooperation with Focus on the Caspian Region" (642709 - CASPIAN - H2020-MSCA-ITN-2014). 


\section{Introduction}

The international system is characterized by increasingly interdependent and asymmetrical relations among the constellations of actors that it is composed of. Although the state remains a central reference in international relations, multilevel and multidimensional relationships make the system very complex. The state, international organizations, non-state actors, club diplomacy and groups of states (e.g., the Group of 20 [G20] and the BRICS grouping of Brazil, Russia, India, China and South Africa) all contribute to this complexity. Their activities might have transnational or intra-state dimensions, resulting in a web of relations that makes the global governance system increasingly multifaceted. In this context, this article examines the relationship between the European Union and the BRICS - two very different actors, pursuing formal and informal integration processes, respectively - and assesses the possibilities and limits of cooperation. This article seeks to understand whether the EU - BRICS relationship reflects a strategic partnership or a structural disjuncture. The article starts by discussing multilateralism as a cooperation-oriented but sometimes interest-driven tool in a diverse and multilevel governance system. It then analyzes EU - BRICS relations, identifying the main drivers and highlighting how global complexity both facilitates and hinders the constitution of this relationship. The article concludes that the EU BRICS relationship is informed by asymmetries and ambivalence that reflect their different sizes, capacities and approaches. Moreover, although there is a shared understanding that cooperation might be beneficial, contradictory rules and perspectives on international order mean this potentially positive relationship is nevertheless embedded in fundamental structural constraints.

\section{Multilateralism and Global Governance in an Increasingly Asymmetrical International System}

As a core concept of international relations, the assertion that state sovereignty is the defining feature of the international system has become increasingly difficult to maintain. New configurations of power resulting from a multi-layered global governance system challenge the notion that the state is the most relevant unit in the system, even while these new configurations may work to bolster state power. This results in ambiguity: global governance defined by multilateralism creates space for collective action, but may also empower individual actions through collective means. Multilateralism "refers to all arrangements wherein three or more states act in concert... Acting multilaterally is perceived to have a value. This value is derived from the appearance of an inclusive, collective, even consensual approach to international action" [Wilkinson, 2015, p. 548]. This is in line with John Ruggie's view of multilateralism as a collectively shared endeavour and reciprocal gains obtained from collaborative action [cited in Wilkinson, 2015, p. 550]. However, while multilateralism may imply convergence it may also reflect an exclusionary dynamic when states refrain from supporting collective action 
that they determine to be against their interests (e.g., in the context of alignments for voting and the use of veto power at the United Nations Security Council). Herein lies the ambiguity inherent to the functioning of multilateral institutions; on the one hand, inclusiveness and collective sharing are implied, but on the other, exclusion and underrepresentation tend to operate as well.

Wilkinson recognizes this, noting that "those multilateral institutions created in the post-World War Two era have been fashioned in such a way that they have tended to assist in the preservation of the United States' pre-eminent role rather than contributed to its dilution" [Wilkinson, 2015, p. 550]. This means, following Nicholas Onuf [1989, p. 261] that most "institutions are bounded by a number of rules. At choice then is not just to follow a rule, but which one, to what extent, and so on." Combined, these observations highlight two main issues. First, the fact that the main rules in the international system were established after World War II means that they are imprinted with the dominant western liberal perspective. Second, because the ensemble of rules that maps action within a given institution leaves room for divergent interpretations, what might be described as out-of-scope action becomes possible. The principle of the responsibility to protect within the United Nations is an interesting illustration of this issue. The locus of its application is defined in a set of rules that have become elastic in their interpretation and used to legitimize interventions in differentiated contexts and by different actors. This elasticity illustrates Onuf's point about how and to what extent international actors follow certain rules. This complicates multilateralism in structures of global governance.

In global terms,

governance is usually linked to the exercise of state sovereignty. However, in an increasingly globalized world, states are bound together by a web of multilateral and bilateral agreements that create mutual binding obligations and place governments under greater scrutiny... It is manifest in the growth of regional trade blocs that cooperate in such areas as trade and the elaboration of common legal frameworks. It is also observed in the power of intergovernmental institutions and in the spread of multinational corporations... Globalization has profound implications for governance, including the erosion of state sovereignty as transnational bodies increasingly mediate national concerns and press for universal laws [Griffiths, 2005, p. 347].

The EU and the BRICS are part of this multi-layered governance structure through the institutionalization of their procedures as well as the establishment of both bilateral and multilateral relations among and between them, and with other actors in the system. International norms, which form the basis for international relations, simultaneously guide action that promotes cooperation - as the very nature of the concept of multilateralism tries to embed and project - justify actions that do not elegantly fit international rules but that, due to different interpretations, might jeopardise this more benign interpretation of multilateralism. One of the most relevant international rules in this regard, and in global governance overall, is the fundamental rule of state sovereignty and non-intervention versus the right to self-determination and protection 
of minorities. Much has been written about the clash of norms implied by these two fundamental principles enshrined in the UN Charter, which leads to competing interpretations of their implementation.

With regard to EU - BRICS relations, the driving norms-taking and norms-making dynamics are not as different as might be expected [on norms taking and norms making, see Checkel, 1999]. In fact, these entail visible cooperative and competitive approaches both within and between the EU and the BRICS. Which norms are taken up? Which are ignored or misinterpreted? These questions are important because differences are revealed in the way these relationships are conceptualized based on fundamental ideas such as sovereignty, the principle of international intervention, security promotion and international order, and in how they are articulated through discourse and practice. Significantly, these differences explain the absence of strategic partnership between the EU and the BRICS. Similarly, discourses and practices of the EU and the BRICS have served different purposes in the interpretation and projection of these concepts in multilateral relations. The discursive strategy of naming the "other" as the "enemy" or as the "partner," for example, works to legitimatize actions and reactions independently of a real, constructed or perceived threat or gain, and provides space for both socialization and resistance. The narrative of "self/other" feeds into the discourse of inclusion/exclusion/not totally in or out, as it is pursued both in the EU (and the West more broadly) and the BRICS [Neumann, 1995, 2006].

These narratives inform notions of an alternative to the western hegemonic order, producing tense relations and images of "otherness" that perpetuate the logic of exclusion/inclusion. This implies that the relations between the EU and the BRICS will remain complicated by the dual weight of the politics of confrontation and cooperation because the image each has of the "other" is informed by their different understandings of the principles and norms of international order. These principles are not fully shared by the different actors in the multilevel system of global governance, where multilateral dynamics have been working to balance difference through dialogue and cooperative arrangements, but with limited reach in terms of the constitutive normative interpretation of these same underlining dynamics. This means that the evolution of EU BRICS relations has been to some extent constrained by this constitutive differential. Progress has been made on practical matters, but cooperation is more difficult when different interpretations of norms are confronted by questions about the legitimacy of normative engagements.

Criticism of the hegemonic western-designed order by the BRICS and the resistance this implies centre on the establishment of a system in which new actors can engage in shaping norms rather than just passively taking norms. However, this is not necessarily a rejection of the western order. Defining itself often as not being antiwestern, the BRICS seek a more inclusive and just international order that challenges western neoliberalism's dominance, while also showing a willingness for integration and recognition as a legitimate actor in this same order. These dynamics of inclusion/ exclusion/not-totally-included/not-fully-excluded are present in the discourse and 
practices that shape relations between the EU and the BRICS. The politics of resistance and socialization, and the reinterpretation of norms while being both norm takers and norm makers, suggests a new way of understanding the logic shaping this relationship. The self-reinforcing discourse of exclusion feeds into the anti-western discourse that the BRICS is challenging the dominant normative order. However, this politics of resistance framed as anti-western or "with the West" opens up the opportunity for mutual engagement. It also supports multilateralism as a tool that might strike a balance between socialization and resistance practices, eventually translating into a "reset" of relations with this hegemonic "western-other" and its unjust international order. ${ }^{2}$ The next section examines the evolution of EU - BRICS relations in order to provide the framework for a discussion of the possibilities for, and implications of, cooperation and competition in bilateral/multilateral relationships embedded in different interpretations of the international global governance system.

\section{EU - BRICS: The Nature of the Actors}

The EU is an international organization with 28 member states, each of which retains decision-making authority in foreign policy, security and defence. This means that, whereas economic agreements follow common agreed-upon rules and procedures, political decisions about international relations and EU engagement with the BRICS are the result of a consensus forged among members regarding a strategic approach. In light of the normative dimension of the socialization/resistance practices noted previously, it is interesting to analyze how the EU's normative power discourse operates to project stability within and beyond its borders, particularly in its relations along the eastern and southern borders. The creation of a circle of friends in its vicinity is a very clear goal of the EU as stated in the Security Strategy of 2003 and reinforced with the approval of the EU Global Strategy [EU, 2016]. ${ }^{3}$ The rationale for advancing this strategy to frame EU relations reflects the understanding of fundamental changes in the international order and their impact on the EU's role and position in the global governance structure. In face of the multiple internal and external challenges, including those in neighbouring areas understood as central to the security and stability of the EU itself, the Global Strategy paves the way for enhanced relations with strategic partners, maintaining the constitutive normative principles of the EU while allowing a more flexible reading of these principles in the development of these relationships.

Recognition of the contested nature of the prevailing order is clear in the wording of this EU statement, as is the need to further advance and revise old and new strategic partnerships alike to facilitate a greater say in international matters:

\footnotetext{
${ }^{2}$ For further discussion of this normative gap between Russia and the West, see Maria Raquel Freire [2017b].

${ }^{3}$ The European Security Strategy (ESS), "A Secure Europe in a Better World," was adopted by the European Council on 12-13 December 2003. It "provides the conceptual framework for the Common Foreign and Security Policy (CFSP), including what would later become the Common Security and Defence Policy (CSDP). The ESS analyses and defines for the first time the EU's security environment, identifying key security challenges and subsequent political implications for the EU" [EEAS Strategic Planning, 2003].
} 
While much has been achieved over the last decade, today an arc of instability surrounds the Union. Further afield, we see conflicts in Africa and security tensions in Asia, while climate change and scarce natural resources harbour the risk of more conflict. At the same time, global growth, interdependence and technological progress enable ever more people to escape poverty and live longer, healthier and freer lives. The EU must confront both the challenges and the opportunities that come with its changed environment. We have a responsibility to protect our citizens while promoting our interests and universal values. The very nature of our Union - a construct of intertwined polities - gives us a unique advantage to steer the way in a more complex, more connected, but also more contested world [EU, Undated].

The EU clearly sees establishing strategic partnerships as a fundamental tool of its external relations, consolidating links at different levels including politics, economics, security and cultural matters. Strategic partnerships "represent a mutual recognition of their respective power-status." [Gratius, 2013, p. 6]. Moreover, by abiding to an agreedupon set of rules to govern areas defined as priorities for both, strategic partners reinforce the relationship as they seek to maximize gains and opportunities for cooperation. For the EU "Strategic Partnerships have been an important instrument for up-grading the role of the EU and the BRICS at the global stage" [Gratius, 2013, p. 6]. This means a cooperative approach to norm making and norm taking, providing room for negotiation and concessions geared at fostering gains. However, the results from such deepening in relations have been far from substantial. "The EU has not been able to use these partnerships to substantially upgrade its relations with the BRICS countries or to prepare itself for the shifting balance of power to the South and to the Asian-Pacific region" [Keukeleire, Mattlin, Hooijmaaijers et al., 2011, p. 1]. A fundamental goal of the 2016 EU Global Strategy is thus to redesign strategic partnerships to address these difficulties and limitations. The intent is to make the EU more central in the international governance structure, projecting its influence and principles externally.

The 2008 global financial crisis and changes in the global governance system have underscored the fact that the EU's socialization practices inside and beyond its borders are generating resistance; the Global Strategy advances a pragmatic approach to meet this challenge. The word "partnerships" appears 35 times in the Global Strategy, referring to the relationships the EU has with other international organizations, states, local private/public agencies as well as other informal international arrangements. Interestingly, although all BRICS countries except South Africa are mentioned, the word "BRICS" is not - while the EU has been developing links with the BRICS as a multilateral group, it is at the same time emphasizing bilateral strategic partnerships with these emerging economies. Not unexpectedly, Russia and China receive special attention. Russia is an important partner for geo-political, economic and energy-related reasons, but cooperation has been hampered by the sanctions imposed after the events in Ukraine and by the overall climate of tension in EU - Russia relations. China, with its stable economic growth and increasingly active role in international affairs, is seen as a very important actor with which the EU should engage further. 
Some basic data support an interpretation of the EU's approach to external relations as driven by a desire to project itself in an increasingly asymmetrical and diverse international system even while conditions become less favourable. For example, as illustrated in Table 1, global demographic figures show the EU experiencing an accentuated downward trend, while the BRICS countries together are set for considerable growth in this regard (despite Russia's long-term problems with demographic decline).

Table 1. The population in the EU, BRICS and other countries, 1960-2060

\begin{tabular}{|l|c|c|c|}
\hline & $\begin{array}{c}\mathbf{1 9 6 0} \\
\mathbf{3 , 0 1 8} \text { million people, } \%\end{array}$ & $\begin{array}{c}\mathbf{2 0 1 5} \\
\mathbf{7 , 3 5 0} \text { million people, } \%\end{array}$ & $\begin{array}{c}\text { 2060 projections } \\
\mathbf{1 0 , 1 8 4} \text { million people, }\end{array}$ \\
\hline European Union & 13.5 & 6.9 & 5.1 \\
\hline Brazil & & 2.8 & 2.3 \\
\hline China & 21.4 & 18.7 & 12.5 \\
\hline India & 14.9 & 17.8 & 17.1 \\
\hline Indonesia & 2.9 & 3.5 & 3.2 \\
\hline Russia & 4 & & 7.8 \\
\hline Other G20 countries & 10.8 & 9.7 & 4 \\
\hline United States & 6.2 & 4.4 & 47.9 \\
\hline Rest of the World & 26.4 & 36.1 & \\
\hline
\end{tabular}

Note. Projections for the European Union with 28 members on the basis of main convergence scenario and for non-EU G20 member projections on the basis of medium fertility variant, 20152100. 1960 population excludes French overseas departments and territories.

Source: Eurostat [2016, fig 1.1, p. 21].

Demographic issues have been on the political agenda for some time. Western countries, including Russia, face severe population declines, whereas Asian and African countries face the reverse trend of rapid population growth. These trends mean that new groupings like the BRICS represent a growing portion of the total world population, giving increasing weight to their global positioning and reach. Economic indicators are also telling. Table 2 compares the share of world gross domestic product (GDP) between 2004 and 2014, and the contrasts are striking. Proportionate with the declining share of global population, the EU's share of world GDP has become smaller during this period compared to the performance of the BRICS, and in particular that of China.

Trade relations between the EU and the BRICS countries have clearly been increasing as indicated by data regarding international trade in goods by partner from 2004 and 2014. Table 3 summarizes data for EU trade in goods with individual BRICS countries. 
Table 2. The share of EU countries, BRICS and other countries in world GDP, 2004-2014

\begin{tabular}{|l|c|c|}
\hline \multicolumn{1}{|c|}{ Share of world gross domestic product } & $\mathbf{2 0 0 4}, \boldsymbol{2 0 1 4 ,} \%$ \\
\hline European Union & 31.4 & 23.8 \\
\hline Brazil & & 3 \\
\hline Canada & 2.3 & 13.4 \\
\hline China & 10.7 & 2.6 \\
\hline India & & 5.9 \\
\hline Japan & 4.5 & \\
\hline Mexico & 1.8 & $14.3^{2}$ \\
\hline Other G20 countries & $10.9^{1}$ & 22.2 \\
\hline United States & 28.1 & 14.8 \\
\hline Rest of the World & 10.3 & \\
\hline
\end{tabular}

Notes:

${ }^{1}$ Argentina, Australia, Brazil, India, Indonesia, Korea, Russia, Saudi Arabia, South Africa and Turkey.

${ }^{2}$ Argentina, Australia, Canada, Indonesia, Korea, Mexico, Russia, Saudi Arabia, South Africa and Turkey.

Source: Eurostat [2016, fig. 6.1, p. 79].

Table 3. EU trade in goods with individual BRICS countries, 2004-2014

\begin{tabular}{|l|c|c|c|c|}
\hline $\begin{array}{l}\text { European Union trade } \\
\text { in goods (billion euro) }\end{array}$ & $\begin{array}{c}\text { 2004 imports } \\
\text { from partner }\end{array}$ & $\begin{array}{c}\text { 2004 exports } \\
\text { to partner }\end{array}$ & $\begin{array}{c}\text { 2014 imports } \\
\text { from partner }\end{array}$ & $\begin{array}{c}\text { 2014 exports } \\
\text { to partner }\end{array}$ \\
\hline Brazil & 21.8 & 14.2 & 9.2 & 29.6 \\
\hline China & 48.4 & 129.2 & 302.1 & 164.6 \\
\hline India & 16.4 & 17.2 & 37.1 & 35.6 \\
\hline Russia & 84.9 & 46.1 & 182.4 & 103.2 \\
\hline South Africa & 15.8 & 16.1 & 18.5 & 23.3 \\
\hline Total & 187.3 & 222.8 & 549.3 & 356.3 \\
\hline
\end{tabular}

Source: Eurostat [2016, fig. 7.4, p. 94].

While not exhaustive, these numbers provide the context for the fundamental goal of the EU's Global Strategy - namely, the need to position itself better internationally. This is to be pursued through different means, including strengthening strategic partnerships with traditional partners, such as the United States and Japan, and also with the emerging economies. "Even though the Strategic Partnerships are a too heterogeneous concept for defining relations with the EU's special ten, they reflect the political will of the EU to be part of the new global game... The EU is also repositioning itself towards non-traditional partners" [Gratius, 2013, p. 2]. This not only signals recogni- 
tion that these states are increasingly relevant in the global governance system, but also that, in the context of challenges to the dominant international order, the EU seems to lack the resources and political will to become an attractive alternative.

A clear illustration presented itself during summer 2015. When the EU found itself in a predicament over what to do with a recalcitrant and economically broke Greece, the BRICS heads of state and government held their 7th summit in Ufa (Russia), inaugurating a New Development Bank and a Contingent Reserve Arrangement (CRA). The contrast could hardly be sharper: where the EU's institutions are under pressure, the BRICS are steadily developing their own institutions; where the EU's mistaken policies are eroding its image, the BRICS offer an ambitious 'Roadmap to 2025' as part of China's gargantuan New Silk Road initiative [van Ham, 2015].

This differential in dynamism is very clear, as is the way it affects socialization and resistance practices. It reflects the EU's diminished presence in the overall global governance system and efforts to regain centrality (as indicated in the Global Strategy). Additionally, it shows that the development of relations with the BRICS still lacks substance, with multilateralism losing ground to bilateral relations between individual BRICS countries and the EU. The special configuration of the BRICS club diplomacy and of its member states clearly plays a role here.

The BRICS members have been described as emerging economies pursuing club politics or network diplomacy. This group of heterogeneous, non-contiguous states bases its decisions on consensus, conferring priority to the sovereignty and autonomous decision-making capacity of states on an equal footing. The main impetus to establish the BRICS was economic, bringing together states whose economic performance and potential warranted the new label of "emerging economy" or "rising power." This common denominator, to the surprise of many, made possible a common agenda defined by shared concerns and goals, including the possibility of political alignment. In fact, plans for an alternative to the western neoliberal international order have quickly become the basis for engagement between these disparate countries. At the first meeting of the group in 2009 (prior to the inclusion of South Africa), the establishment of "a more democratic and just multi-polar order based on the rule of international law, equality, mutual respect, cooperation, coordinated action, and collective decisionmaking of all states" was a clearly stated goal [BRIC, 2009].

The agenda that followed has highlighted these principles as differentiating the group's global reach in international politics. The mobilization of resources through institutionalized mechanisms such as the New Development Bank (NDB) in support of projects to promote sustainable development and growth in developing countries complements the efforts of financial and multilateral regional institutions on global growth [BRICS, 2014]. This illustrates the autonomous capacity of the group to take new initiatives to clearly set the agenda [Cooper, 2016, p. 110]. The BRICS has become a norm maker and is repositioning itself as an influential actor in the governance system. As John Kirton and Marina Larionova [2012, p. 9] argue, summit declarations 
clearly demonstrate that the agenda has been continuously growing with new issues included every year: the group "has evolved its global governance functions, moving from its focus on deliberation to direction-setting, decision-making, delivery and the development of BRICS governance institutions."

The BRICS has been widening its agenda to include "new challenges related to inequalities, politics of protectionism, isolationism, absence of confidence," according to Svetlana Lukash. ${ }^{4}$ This provides for a more balanced and democratic order with the fundamental goal of growth, rather than being a substitution for other international organizations. This idea of complementarity has been underlined in different instances. Pavel Knyazev [2016] notes that the BRICS plays a leading role and sets an example: "The political agendas of the BRICS states may not coincide at times, but in the philosophy of the BRICS there is nothing anti-, the BRICS are always a pro- and not a contra-. This does not mean however that there is not a 'goal of geopolitics counterbalance', which to the group's understanding is necessary to confer more justice to the international order." This positioning has allowed the change from "a liberal-unilateral to a developmental-multipolar set of social claims" [Mielniczuk, 2013, p. 1087]. However, this commitment to a more just order does not necessarily imply the demise of the West or the replacement of western-led institutions, with which BRICS countries have been working, and want to continue working [Freire, 2017a]. In this regard, the tension between the dynamics of socialization and resistance is clear - the role of the BRICS is limited in the sense that it is challenging the international order from which it has emerged and in which it continues to benefit.

This desire to promote an alternative order without directly confronting the existing one creates potential obstacles for the BRICS. However, this alternative order does not need to be fundamentally different as long as it is more inclusive and provides better opportunities for less-favoured actors. This points to a "hybrid order" that allows global integration and a differentiated approach to relations that does not adhere only to the principles of the liberal order [Stephen, 2014, p. 914]. The multi-layered, polycentric and sectorial nature of global governance makes it flexible enough to adjust to different configurations of power, as well as to the different means and goals of distinct actors. In this way, the polycentric conception of global governance does not mean necessarily an equal order; instead, "there is a recognition that the system is institutionally biased or distorted in favour of powerful states and vested interests" [Held, 2014, p. 66; see also Freire, 2017a].

The BRICS agenda has been widening as the group has become more consolidated through more institutionalization, including establishing common institutions such as the NDB, and a more institutionalized format for regular summits. The economic dimension has remained central despite the broader focus of the agenda to include "the overarching objective of generating strong, sustainable and balanced global growth, as well as financial regulation and reforming international financial institutions" [Lario-

${ }^{4}$ Remarks at a conference on "G20 and BRICS: New Global Governance Institutions," at the Russian Presidential Academy of National Economy and Public Administration, Moscow, Russia, 26 October 2016. 
nova and Shelepov, 2015, p. 45]. In Swaran Singh's view [2013, p. 396] consolidation should focus on the economic dimension, whereas the BRICS should "remain cautious" on political and security matters. ${ }^{5}$ Thus, two main ideas can be emphasized. First, despite being what many saw as an improbable grouping, the BRICS committed to a common agenda and has delivered on it, including the creation of common institutions. Second, the focus on global governance implies new institutions but overall these are not intended to overthrow the current system. Rather they seek a balance between the goal of challenging the western neoliberal order while not dismissing it.

\section{EU Going Global, BRICS Already Global?}

The agendas of the EU and the BRICS have common goals such as improved economic relations, increased development, and the creation of a more stable and secure international environment. According to Susanne Gratius [2013, p. 2], declarations made at BRICS summits concentrate on global issues for which common positions on the main priorities have been consolidated, namely peace, security, development and cooperation. Moreover, it is understood that a strong image of the group would allow for a stronger positioning of the BRICS in the international system, with gains at both the collective and individual levels [Cheng, 2015, p. 373]. The preamble of "The Strategy for BRICS Economic Partnership" highlights the group's relevance in global terms and its agenda moving forward:

BRICS is a dialogue and cooperation platform among Member States (Brazil, Russia, India, China and South Africa) which together account for $30 \%$ of global land, $43 \%$ of global population and $21 \%$ of the world's Gross Domestic Product (GDP), $17.3 \%$ of global merchandise trade, $12.7 \%$ of global commercial services and $45 \%$ of world's Agriculture Production. This platform aims to promote peace, security, prosperity and development in multipolar, interconnected and globalized world. The BRICS countries represent Asia, Africa, Europe and Latin America, which gives their cooperation a transcontinental dimension making it especially valuable and significant [BRICS, 2015].

In official EU documents, the same goals for external relations have been present since early on. However, both the measures taken to achieve these goals and the understandings about development and security informing them have been different. For the EU, these are normative concepts that should be broadly understood; the BRICS countries tend to take a sovereigntist approach informed by a South-South discourse of development emphasizing a more equal and less hierarchical international system. The EU promotes the western neoliberal order, including in its external relations, and adds a normative dimension. However, it has been claimed that

the role of values and norms in EU foreign policy deserves an honest re-assessment. A shift towards a more interest-oriented approach has been discernible in recent debates on the EU's

\footnotetext{
${ }^{5}$ On this issue see also Ramesh Thakur [2014].
} 
external affairs, including its neighbourhood policy. The earlier idealism should not be replaced with cynicism, relativism or even realism in the sense of accepting that hard power ultimately dominates the liberal aspiration for a norms-based international order. But the EU needs to be more realistic (as distinct from realist), not least for the sake of its credibility [Raik, Helwig and Iso-Markku, 2015, p. 4].

Furthermore, although the EU aspires to become a global actor (as is made clear in the Global Strategy), the BRICS have already achieved global reach despite the diversity of its members' geography, nature and economic size. Nevertheless, and despite the differences between the EU and the BRICS in terms of the degree of integration, size of economies and growth performance, these actors are very much engaged. This is the case not only economically but also politically, even though in many instances their political agendas are misaligned. Katarína Králiková [2014, p. 248] has suggested that despite political discourse that often seems unfavourable to a closer rapprochement, the EU is the BRICS's biggest trading partner and has sought to assist the five countries in overcoming various problems. Thus, opportunities for cooperation exist and should be better acknowledged by the BRICS. Nevertheless, as Králiková notes, the EU should engage with the BRICS in innovative ways to contribute "to the upgrade of domestic production; the improvement of research, development and innovation; and better information sharing in the global knowledge networks and markets."

As Gratius [2013, p. 4] writes, "neither the EU nor the BRICS have ever suggested a group-to-group dialogue." She understands this to be the result of divergent world views, and of the fact that the BRICS countries have become "veto players against the West. This corresponds to the rhetoric of establishing an alternative global order:

Reflecting the major differences between the five countries, the intensification of the relations between the BRICS countries does not mean that they do systematically form a bloc. Nevertheless, the increasingly dense networks between the five countries are based on a common goal: that is to advance the G20 and other new multilateral settings as an international forum and to counter what they perceive as an undemocratic and unjust Western-dominated multilateral world. The BRICS phenomenon should therefore be seen as reflecting a general shift in the international balance of power with the centre of gravity moving from the Euro-Atlantic to the Asia-Pacific area and from the North to the South [Keukeleire, Mattlin, Hooijmaaijers et al., 2011, p. 1].

Additionally, BRICS summit declarations do not pay special attention to the EU, just as the EU Global Strategy does not mention the BRICS. This again points to these two groups engaging less at the multilateral level, and more in bilateral dealings. Gratius [Gratius, 2013, p. 4] writes that one argument is the level of economic interdependence or cooperation: "China's export boom and economic growth depends highly on the EU (its main trade partner), while China is the EU's second import and export market. Russian oil and gas exports concentrate on the EU and Moscow is not only Brussels main energy supplier, but also an important political headache, particularly when it comes to solve international conflicts such as the nuclear problem with Iran 
or the civil war in Syria." The potential of multilateralism to promote cooperation and informal integration benignly is not really being achieved in EU - BRICS relations, where the bilateral channel clearly defines interests and sets agendas. Consequently, in the global governance system the EU and the BRICS acknowledge the relevance of the "other" but remain apart on fundamental issues, especially on redesigning the international order to be more inclusive, in part due to the competing socialization/resistance dynamics in the BRICS "anti-West" and "with the West" discourse and practice. Despite opportunities for further integration, especially those arising from economic activities, the difficulties of framing this informal integration within a strategic partnership are evident. Structural disjuncture seems to prevail.

\section{Strategic Partnership or Structural Disjuncture?}

Although the EU has prioritized developing strategic partnerships as a way to deepen linkages with particular countries, the fact that existing strategic partnerships have not produced the expected informal integration results, including with the BRICS members, raises questions about the substance of EU relations with the BRICS. Three ideas seem relevant in this regard: first, the EU has thus far not developed a strategic approach toward the BRICS as a group despite recognizing its leverage and increasing influence in international relations; second, bilateral strategic partnerships between the EU and individual BRICS countries have not produced substantial relationships despite increasing trade cooperation; and third, the multilateral approach has been losing pace in the face of bilateral and more traditional relations with individual BRICS countries, signalling the difficulties of engaging with actors pursuing distinct visions and seeking alternative approaches to the western-led order. In fact, "over the longer term, all of the BRICS countries appear intent on reducing Western influence in global institutions. Traditional multilateralism is, therefore, not a reliable basis for strategy in a neo-Westphalian world" [Dennison, Gowan, Kundnani et al., 2013, p. 4].

These ideas point to a structural disjuncture in EU - BRICS relations in the sense that neither has invested in developing a common agenda or shared approach to strategic issues of common interest. Their differentiated agendas with respect to the configuration of the international system is a structural disjuncture rendering close cooperation difficult except in pragmatically selected areas of bilateral cooperation. Also, the level and size of these relationships vary to a great extent, with South Africa, for example, representing a very small share of EU trade relations, whereas China and Russia are significant partners in many areas. The case of Russia is interesting, as despite their interdependence relations between the EU and Russia are complicated by the events in Ukraine and Syria. As a result, Russia has been using the BRICS as a forum to find partners to compensate for the negative effects of strained relations with the EU. This underscores what Gratius [2013, p. 6] describes as a structural hurdle that must be overcome in order to deepen their relations: "for the EU it will be much easier to rely on traditional alliance on global issues than to move towards the positions of the BRICS 
countries highly influenced by the traditional interpretation of national sovereignty, Realpolitik and non-interference in domestic affairs."

Nevertheless, despite the limits of strategic partnerships, they do hold significant political value. What might be needed is the promotion of socialization practices, from all sides, that can contribute to a joint definition of the contents of these partnerships, taking account of the differences between the partners. At the bilateral level this is slowly being attempted in EU relations with BRICS countries; however, at the multilateral level there are no clear signals of strategic thinking about EU - BRICS structured dialogue. Given the growing complexity of the international system and the power shifts that are becoming evident in its reconfiguration, this could be a way forward in EU BRICS relations. As Onuf [1989] puts it, which rules are followed, who follows them and how they are followed involve choices. Both the EU and the BRICS are norm takers and norm makers. What they choose to do in these roles will determine whether their relationship will open new avenues for cooperation and growth, or instead pave the way for competition and rivalry.

\section{References}

BRIC (2009) "Joint Statement of the BRIC Countries' Leaders." Yekaterinburg, 16 June. Available at: http://www.brics.utoronto.ca/docs/090616-leaders.html (November 2016).

BRICS (2014) "Agreement on the New Development Bank." Fortaleza, Brazil, 15 July. Available at: http://www.brics.utoronto.ca/docs/140715-bank.html (November 2016).

BRICS (2015) “The Strategy for BRICS Economic Partnership.” Ufa, Russia, 9 July. Available at: http:// www.brics.utoronto.ca/docs/150709-partnership-strategy-en.html (March 2017).

Checkel, Jeffrey T. (1999) "Norms, Institutions and National Identity in Contemporary Europe." International Studies Quarterly 43 (1), pp. 84-114. doi: 10.1111/0020-8833.00112.

Cheng, Joseph Y.S. (2015) "China's Approach to BRICS.” Journal of Contemporary China 24 (92), pp. 357-75. Routledge. doi: 10.1080/10670564.2014.932518.

Cooper, Andrew F. (2016) BRICS: A Very Short introduction. Oxford: Oxford University Press.

Dennison, Susi, Richard Gowan, Hans Kundnani et al. (2013) "Why Europe Needs a New Global Strategy.” Policy Brief ECFR/90, October. European Council on Foreign Relations. Available at: http://www. ecfr.eu/page/-/ECFR90_STRATEGY_BRIEF_AW.pdf (March 2017).

EEAS Strategic Planning (2003) "European Security Strategy: A Secure Europe in a Better World." 12 December. European Union. Available at: http://europa.eu/globalstrategy/en/european-securitystrategy-secure-europe-better-world (March 2017).

European Union (2016) "Shared Vision, Common Action: A Stronger Europe. A Global Strategy for the European Union's Foreign and Security Policy.” June. Brussels. Available at: http://eeas.europa.eu/ archives/docs/top_stories/pdf/eugs_review_web.pdf (March 2017).

European Union (Undated) "The European Union in a Changing Global Environment." Brussels. Available at: http://europa.eu/globalstrategy/en/european-union-changing-global-environment (March 2017).

Eurostat (2016) “The EU in the World.” Luxembourg: European Union. Available at: http://ec.europa. eu/eurostat/documents/3217494/7589036/KS-EX-16-001-EN-N.pdf/bcacb30c-0be9-4c2e-a06d4b1daead493e (March 2017). 
Freire, Maria Raquel (2017a) "Political Dynamics within the BRICS in the Context of Multilayered Global Governance.” In: Marina Larionova and John Kirton, eds., BRICS and Global Governance. Abdingdon: Routledge.

Freire, Maria Raquel (2017b) "Ukraine and the Restructuring of East-West Relations." In: Roger E. Kanet, ed The Russian Challenge to the European Security Environment. London: Springer International Publishing.

Gratius, Susanne (2013) “The EU and Its 'Strategic Partnerships' with the BRICS.” May. Konrad Adenauer Stiftung. Available at: http://www.kas.de/wf/doc/9922-1442-2-30.pdf (March 2017).

Griffiths, Martin (2005) “Good Governance.” In: Martin Griffiths, ed Encyclopedia of International Relations and Global Politics. Abdingdon: Routledge, pp. 347-49.

Held, David (2014) “The Diffusion of Authority.” In: Thomas G. Weiss and Rorden Wilkinson, eds., International Organization and Global Governance. Abingdon: Routledge, pp. 62-72.

Keukeleire, Stephan, Mikael Mattlin, Bas Hooijmaaijers et al. (2011) "The EU Foreign Policy Towards the BRICS and other Emerging Powers: Objectives and Strategies." Directorate-General for External Policies of the Union, Directorate B, Policy Department. Ad Hoc Study, EXPO/B/AFET/FWC/200901/LOT2/09, October. Brussels: European Parliament. Available at: http://lirias.kuleuven.be/bitstream/123456789/321923/1/The+EU+Foreign+Policy+towards+the+BRICS+and+other+Emergin g+Powers+-+Objectives+and+Strategies+.pdf (March 2017).

Kirton, John J. and Marina Larionova (2012) "From Reform to Crisis Response: Addressing the Key Global Issues.” In: John J. Kirton and Marina Larionova, eds., BRICS: The 2012 New Delhi Summit. London: Newsdesk, pp. 8-9. Available at: http://www.brics.utoronto.ca/newsdesk/delhi (November 2016).

Knyazev, Pavel (2016) "Communication presented at the conference on "G20 and BRICS - New Global Governance Institutions.” 25 October. Moscow: Russian Presidential Academy of National Economy and Public Administration.

Králiková, Katarína (2014) “BRICS: Can a Marriage of Convenience Last?” European View 13 (2), pp. 243-50. doi: 10.1007/s12290-014-0326-2.

Larionova, Marina and Andrei Shelepov (2015) "Is BRICS Institutionalization Enhancing Its Effectiveness?" In: Marek Rewizorski, ed The European Union and the BRICS: Complex Relations in the Era of Global Governance. Leiden: Springer, pp. 39-56.

Lukash, Svetlana (2016) "Communication presented at the conference on "G20 and BRICS - New Global Governance Institutions.” 25 October. Moscow: Russian Presidential Academy of National Economy and Public Administration.

Mielniczuk, Fabiano (2013) "BRICS in the Contemporary World: Changing Identities, Converging Interests.” Third World Quarterly 34 (6), pp. 1075-90. Routledge. doi: 10.1080/01436597.2013.802506.

Neumann, Iver (1995) Russia and the Idea of Europe: Identity and International Relations. London: Routledge.

Neumann, Iver (2006) "European Identity and Its Changing Others.” No. 710. Oslo: Norwegian Institute of International Affairs. https://www.files.ethz.ch/isn/27901/710.pdf (March 2017).

Onuf, Nicholas Greenwood (1989) World of Our Making: Rules and Rule in Social Theory and International Relations. Columbia SC: University of South Carolina Press.

Raik, Kristi, Niklas Helwig and Tuomas Iso-Markku (2015) "Crafting the EU Global Strategy: Building Blocks for a Stronger Europe.” FIIA Briefing Paper 188, December. Helsinki: Finish Institute for International Affairs. Available at: http://www.fiia.fi/en/publication/553/crafting_the_eu_global_strategy/ (March 2017).

Singh, Swaran (2013) "Future of Golden BRICS." Strategic Analysis 37 (4), pp. 393-97. doi: 10.1080/09700161.2013.802513. 
Stephen, Matthew (2014) "Rising Powers, Global Capitalism and Liberal Global Governance: A Historical Materialist Account of the BRICs Challenge.” European Journal of International Relations 20 (4), pp. 912-38. doi: 10.1177/1354066114523655.

TASS (2015) "BRICS Becomes New Center of Multipolar World - Russian Diplomat.” 9 July. Available at: http://tass.com/russia/807139 (March 2017).

Thakur, Ramesh (2014) "How Representative Are BRICS?" Third World Quarterly 35 (10), pp. 1791808. Routledge. doi: 10.1080/01436597.2014.971594.

van Ham, Peter (2015) "The BRICS as an EU Security Challenge: The Case for Conservatism." The Hague: Clingendael Institute. https://www.clingendael.nl/pub/2015/the_brics_as_an_eu_security_ challenge/ (March 2017).

Wilkinson, Rorden (2015) "Multilateralism.” In: Martin Griffiths, ed Encyclopedia of International Relations and Global Politics. Abingdon: Routledge. 


\title{
ЕС и БРИКС: стратегическое партнерство или структурное расхождение?'
}

\author{
М.Р. Фрейре
}

Фрейре Мария Ракель - PhD, доцент, председатель Программы Жана Моне, Департамент международных отношений, факультет экономики, Коимбрский университет; Av Diasda Silva 165, 3004-512 Coimbra, Portugal; E-mail: rfreire@fe.uc.pt

Система международных отношений все больше характеризуется взаимозависимостью и асимметричными взаимосвязями между образующими ее группами акторов. Несмотря на то что государства продолжают играть ключевую роль в международных отношениях, система по своей структуре гораздо более сложная, учитывая многоуровневые и многомерные взаимосвязи. Государства, международные организации, неправительственные акторы, структуры клубной дипломатии и группы государств (например, «Группа двадцати» и БРИКС) формируют эту сложную систему, в связи с этим система глобального управления становится все более многосторонней. Принимая во внимание данные тенденции, автор статьи исследует взаимоотношения Европейского союза (ЕС) и БРИКС, для того чтобы определить, как два сильно отличающихся друг от друга актора, осуществивших формальную и неформальную интеграцию, выстроили свое взаимодействие, а также возможности и ограничения их сотрудничества в условиях асимметричной и различающейся международной системы. Таким образом, автор стремится найти ответ на вопрос, являются ли взаимоотношения ЕС БРИКС стратегическим партнерством или же демонстрируют структурное расхождение? В начале статьи автор рассматривает многосторонность как механизм, ориентированный на сотрудничество, хотя иногда и стимулируемый национальными интересами в условиях неоднородной и многоуровневой системы управления. Затем следует анализ взаимоотношений ЕС и БРИКС, в рамках которого автор определяет основные стимулы и то, как сложный контекст геополитических отношений упрощает или жее, наоборот, затрудняет взаимоотношения. В заключительном разделе статьи автор приходит к выводу, что модель взаимоотношений ЕС и БРИКС сформировалась на основе асимметрии и амбивалентности. Это, в свою очередь, определило масштаб, возможности и подходы, а также понимание того, что подобное сотрудничество может быть взаимовыгодным, однако в то же время развитию взаимодействия мешают несовместимые правила и принципы в отношении международного порядка, которые приводят к фундаментальным структурным барьерам.

Ключевые слова: Европейский союз; БРИКС; глобальное управление; многосторонность; международные нормы

Для цитирования: Фрейре М.Р. ЕС и БРИКС: стратегическое партнерство или структурное расхождение? // Вестник международных организаций. 2017. Т. 12. № 3. C. 182-200. DOI: 10.17323/1996-7845-201703-182

\section{Литература}

BBC (2014) BRICS: Building a New Development Bank // BBC News. 11 July.

Checkel J. (1999) Norms, Institutions, and National Identity in Contemporary Europe // International Studies Quarterly. No. 43 (1). P. 83-114.

Cheng J.Y.S. (2015) China’s Approach to BRICS // Journal of Contemporary China. No. 24 (92). P. $357-375$.

${ }^{1}$ Статья поступила в редакцию в ноябре 2016 г.

Автор благодарит за финансирование своего исследования Инновационную сеть профессиональной подготовки им. Марии Склодовской-Кюри (ITN-ETN) Программы ЕС «Горизонт 2020» в рамках грантового соглашения «Прикаспийский регион: Программа для будущих экспертов в сфере развития и сотрудничества в регионе Каспия» (642709 - CASPIAN - H2020-MSCA-ITN-2014). 
Cooper A.F. (2016) The BRICS // A Very Short Introduction. Oxford: Oxford University Press.

Dennison S., Gowan R., Kundnani H., Leonard M., Witney N. (2013) Why Europe Needs a New Global Strategy // European Council on Foreign Relations Policy Brief. No. 90 (October). Режим доступа: http:// www.ecfr.eu/page/-/ecfr90_strategy_brief_aw.pdf (дата обращения: 01.11.2016).

ESS (2003) European Security Strategy. A Secure Europe in a Better World, European Council. 12-13 December. Режим доступа: https://europa.eu/globalstrategy/en/european-security-strategy-secure-europe-betterworld (дата обращения: 01.11. 2016).

European Parliament (2011) The EU Foreign Policy Towards the BRICS and other Emerging Powers: Objectives and Strategies. October. Режим доступа: https://lirias.kuleuven.be/bitstream/123456789/321923/1/ The +EU +Foreign + Policy+towards+the+BRICS+and+other+Emerging +Powers +-+Objectives + and + Stra tegies+.pdf (дата обращения: 01.11. 2016).

Eurostat (2016) The EU in the World. Luxembourg: Publications Office of the European Union. Режим доступа: http://ec.europa.eu/eurostat/documents/3217494/7589036/KS-EX-16-001-EN-N.pdf/bcacb30c0be9-4c2e-a06d-4b1daead493e (дата обращения: 01.11. 2016).

Freire M.R. (forthcoming 2017a) Ukraine and the Restructuring of East-West Relations // The Russian Challenge to the European Security Environment / Roger E. Kanet (ed.). L.: Palgrave.

Freire MR. (forthcoming 2017b) Political Dynamics within the BRICS in the Context of Multilayered Global Governance // BRICS in the System of Global Governance / M. Larionova (ed.). Aldershot: Ashgate.

Gratius S. (2013) The EU and its 'Strategic Partnerships' with the BRICS. Konrad-Adenauer-Stiftung. May. Режим доступа: http://www.kas.de/wf/doc/9922-1442-2-30.pdf (дата обращения: 01.11. 2016).

Griffiths M. (ed.) (2005) Encyclopaedia of International Relations and Global Politics. Oxon: Routledge. P. 549-551.

Ham P. van (2015) The BRICS as an EU Security Challenge. The Case for Conservatism. Netherlands Institute of International Relations Clingendael. Clingendael Report. September. Режим доступа: https://www.clingendael.nl/pub/2015/the_brics_as_an_eu_security_challenge/ (дата обращения: 01.11. 2016).

Knyazev P. (2016) Communication Presented at the International Conference "G20 And BRICS - New Global Governance Institutions”, BRICS Research Group, Russian Presidential Academy of National Economy and Public Administration. Moscow, 25 October.

Králiková K. (2014) BRICS: Can a Marriage of Convenience Last? // European View. No. 13. P. 243-250.

Larionova M., Kirton J. (2012) From Reform to Crisis Response: Addressing the Key Global Issues, BRICS: The 2012 New Delhi Summit. Режим доступа: http://ssrn.com/abstract=2335358 (дата обращения: 01.11. 2016).

Larionova M., Shelepov A. (2015) Is BRICS Institutionalization Enhancing Its Effectiveness? // The European Union and the BRICS. Complex Relations in the Era of Global Governance / M. Rewizorski (ed.). L.: Springer.

Lukash S. (2016) Russian G20 Sherpa, Deputy Head of the Presidential Experts' Directorate. Communication presented at the International conference "G20 and BRICS - new global governance institutions", BRICS Research Group, Russian Presidential Academy of National Economy and Public Administration. Moscow, 25 October.

Mielniczuk F. (2013) BRICS in the Contemporary World: Changing Identities, Converging Interests // Third World Quarterly. No. 34. P. 1075-1090.

Neumann I. (1995) Russia and the Idea of Europe: Identity and International Relations. L.: Routledge.

Neumann I. (2006) European Identity and its changing Others, Norwegian Institute of International Affairs, NUPI Paper No. 710. Режим доступа: https://www.files.ethz.ch/isn/27901/710.pdf (дата обращения: 01.11. 2016).

Onuf N. (1989) World of Our Making. Coumbia, SC: University of South Carolina Press.

President of Russia (2009) Joint Statement of the BRIC Countries' Leaders, Yaketerinburg, Russian Federation. 16 June. Режим доступа: http://en.kremlin.ru/supplement/209 (дата обращения: 01.11. 2016).

Raik K., Helwig N., Iso-Markku T. (2015) Crafting the EU Global Strategy. Building Blocks for a Stronger Europe. FIIA Briefing Paper. No. 188 (December). 
Ryabkov S. (2015) BRICS Becomes New Center of Multipolar World - Russian Diplomat, TASS. 9 July. Режим доступа: http://in.rbth.com/news/2015/07/09/brics_becomes_new_center_of_multipolar_world_ russian_diplomat_44125 (дата обращения: 01.11. 2016).

Singh S. (2013) Future of Golden BRICS // Strategic Analysis. No. 37 (4). P. 393-397.

Stephen M.D. (2014) Rising Powers, Global Capitalism and Liberal Governance: A Historical Materilaist Account of the BRICs Challenge // European Journal of International Relations. Vol. 20. No. 4. P. 912-938.

Thakur R. (2014) How Representative are BRICS? // Third World Quarterly. No. 35 (10). P. 1791-1808.

The Strategy for BRICS Economic Partnership (2015) Released at the Ufa Summit. 9 July. Режим доступа: http://www.brics.utoronto.ca/docs/150709-partnership-strategy-en.html (дата обращения: 01.11. 2016).

Weiss T.G., Wilkinson R. (2013) International Organization and Global Governance. Oxon: Routledge.

Wilkinson R. (2005) Multilateralism // Encyclopaedia of International Relations and Global Politics / M. Griffiths (ed.). Oxon: Routledge. P. 549-551. 